J URARARASI TEKIIK SIPIL 


\section{JURNAL GRADASI TEKNIK SIPIL POLITEKNIK NEGERI BANJARMASIN}

Jurnal Gradasi Teknik Sipil diterbitkan oleh Pusat Penelitian dan Pengabdian Kepada Masyarakat Politeknik Negeri Banjarmasin. Ruang lingkup makalah meliputi Bidang Teknik dan Manajemen dengan konsentrasi Bidang Transportasi, Geoteknik, Struktur, Keairan dan Manajemen Konstruksi. Isi makalah dapat berupa penyajian isu aktual di bidang Teknik Sipil, review terhadap perkembangan penelitian, pemaparan hasil penelitian, dan pengembangan metode, aplikasi, dan prosedur di bidang Teknik Sipil. Makalah ditulis mengikuti panduan penulisan.

\section{Penanggung Jawab}

Nurmahaludin, ST, MT.

\section{Dewan Redaksi}

Ketua $\quad$ : $\quad$ Dr. Fitriani Hayati, ST, M.Si.

Anggota $\quad$ : $\quad$ Riska Hawinuti, ST, MT.

Nurfitriah, S.Pd, MA.

Ir. Rusliansyah, M.Sc.

\section{Reviewer}

Dr. Ir. Yanuar Jarwadi Purwanto, MS. (Institut Pertanian Bogor)

Dr. Ir. Achmad Rusdiansyah, MT. (Universitas Lambung Mangkurat)

Dr. Ir. M. Azhar, M. Sc. (Institut Sains dan Teknologi Nasional)

Dr. Ir. Endang Widjajanti, MT. (Institut Sains dan Teknologi Nasional)

Joni Irawan, ST, MT. (Politeknik Negeri Banjarmasin)

Yusti Yudiawati, ST, MT. (Politeknik Negeri Banjarmasin)

\section{Editing dan Tata Bahasa}

Nurfitriah, S.Pd., MA.

\section{Desain dan Tata Letak}

Abdul Hafizh Ihsani

\section{Alamat Redaksi}

Jurusan Gradasi Teknik Sipil Politeknik Negeri Banjarmasin, Jl. Brigjen H. Hasan Basri 70123 Banjarmasin Telp/Fax 0511-3307757; Email: gradasi.tekniksipil@poliban.ac.id 


\section{JURNAL GRADASI TEKNIK SIPIL}

\section{DAFTAR ISI}

Perencanaan Struktur Atas Jembatan Komposit Sungai Nipah Desa Darul Aman Kecamatan Rupat ...( 1 - 9 )

Nur Aspaliza, Indriyani Puluhulawa, Armada

Perencanaan Jembatan Rangka Baja Pelengkung Sungai Liong ...( 10 - 21 )

Febry Suhendra, Faisal Ananda, Alamsyah

Pengaruh Agregat Setempat Terhadap Nilai Indeks dan Biaya pada Analisa Satuan

Pekerjaan Beton f'c $20 \mathrm{MPa}$... ( 22 - 29 )

Muhammad Humaidi, Khairil Yanuar, Aunur Rafik

Pengaruh Posisi, Jumlah Layer Dan Mutu Kayu Terhadap Balok Laminasi Kayu Mahang Dan Kayu Meranti ...( 30 - 35 )

Indriyani Puluhulawa

Pengaruh Supeltas Terhadap Tingkat Pelayanan Simpang Jalan Trans KalimantanKomplek Griya Permata ...( $36-44)$

Riska Hawinuti

Perancangan Lapis Pondasi Agregat Tanpa Penutup Aspal Gradasi Batas Tengah Menggunakan Claystone ...( 45 - 54 )

Ahmad Norhadi, H. Muhammad Fauzi, Akhmad Marzuki, Zuraida 


\title{
Pengaruh Supeltas Terhadap Tingkat Pelayanan Simpang Jalan Trans Kalimantan-Komplek Griya Permata
}

\author{
Riska Hawinuti ${ }^{1 *}$ \\ ${ }^{1}$ Dosen Jurusan Teknik Sipil Politeknik Negeri Banjarmasin \\ email:*1 riskahawinuti@poliban.ac.id (corresponding author)
}

\begin{abstract}
Abstrak
Kemunculan "Supeltas" (Sukarelawan Pengatur lalulintas) terjadi seiring dengan bertambah panjangnya antrian kendaraan yang akan melakukan pergerakan membelok menuju arah tertentu. Supeltas sendiri adalah orang (bukan petugas resmi dari pemerintah) yang mengatur lalulintas dengan mengharapkan pemberian sukarela dari pengguna jalan tersebut. Seringkali, aktivitas ini melanggar aturan-aturan jalan dan memperparah kemacetan yang ada. Tujuan penelitian ini adalah mengetahui nilai kinerja simpang tidak bersinyal akibat pengaruh keberadaan "Supeltas".

Perhitungan dilakukan dengan menggunakan data primer berupa data geometrik jalan, volume arus lalulintas dan kondisi lingkungan, serta data sekunder berupa peta lokasi dan data jumlah penduduk tahun ke $n$. Pengumpulan data lalulintas dilakukan dengan cara perhitungan manual selama 2 periode pada hari Selasa, Rabu dan Kamis pukul pagi 06.30-08.30, siang pukul 12.00-14.00 dan sore pukul 16.30-18.30 WITA untuk masingmasing kondisi. Perhitungan mengacu pada MKJI 1997.

Hasil perhitungan diperoleh nilai derajat kejenuhan (DS) tanpa adanya "Supeltas" sebesar 1,816 dan dengan adanya "Supeltas" sebesar 1,525. Nilai DS ini melebihi ketentuan MKJI sebesar 0,75. Dapat disimpulkan bahwa keberadaan "Supeltas" membuat dampak positif untuk mengurangi derajat kejenuhan dengan penurunan DS sebesar $16,02 \%$.
\end{abstract}

Kata kunci-Arus Lalulintas, Derajat Kejenuhan dan Simpang Tidak Bersinyal

\begin{abstract}
The appearanced of the peoples called "Supeltas" (Sukarelawan Pengatur lalulintas=Traffic Regulatory Volunteers) occurs along with the increasing number of queue vehicles that will turn towards the road. Supeltas itself is persons (not official from the government) who manage traffic flow expecting voluntari giffts from people passing through the road. Often, these activities broke the road rules and exacerbate existing congestion. The purpose of this study was to compare the performance of unsignalizes intersections between the existing and non-existent of "Supeltas" it self.

The requirement data needed are the primary data in the form of geometric data, traffic conditions, traffic and environmental conditions data, and secondary data in the form of population and location map. Traffic data collection is done using manual calculation for 2 periods on Tuesday, Wednesday and Thursday at 06.30-08.00 in the morning, noon 12.00-14.00 and afternoon at 16.30-18.30 WITA for each condition of rush hours. The calculation refers to MKJI 1997.

The calculation results obtained by the degree of saturation (DS) without the "Supeltas" amounting to 1,816 and with the provision "Supeltas" of 1,525, this DS value exceeds the IHMC (Indonesian Highway Manual Capacity) previsions 0,75. It can be concluded that the existence of "Supeltas" made a positive impact to reduce the number of DS where it decreased $16.02 \%$.
\end{abstract}

Keywords - Traffic Flow, Degree of Saturation and Unsignalized Junction 


\section{PENDAHULUAN}

Persimpangan mempunyai pengaruh besar terhadap sistem transportasi jalan, karena tingkat efisiensi, kecepatan, keamanan dan tingkat pelayanan simpang dan jalan tergantung dari perencanaan persimpangan itu sendiri. Setiap persimpangan mencakup pergerakan lalulintas orang dan alat transportasi secara menerus dan saling berpotongan pada satu atau lebih dari ruas persimpangan. Inilah penyebab terjadinya benturan antar sesama pengguna jalan sehingga dibutuhkannya pengendalian pergerakan lalulintas pada simpang tersebut. Penurunan kinerja simpang mengakibatkan terjadinya kerugian bagi pengguna jalan karena terjadinya penurunan kecepatan pergerakan, peningkatan antrian kendaraan dan peningkatan tundaan yang menyebabkan naiknya biaya operasional kendaraan dan menurunnya tingkat kualitas lingkungan.

Kondisi simpang tak bersinyal di jalan antar kota khususnya simpang Jalan Trans Kalimantan dan Komplek Griya Permata, Handil Bakti, Barito Kuala cenderung padat yang mengakibatkan meningkatnya jumlah angka kecelakaan dan mengganggu kondisi psikologi pengendara akibat antrian kemacetan. Hal ini disebabkan ruas jalan mayor (Jalan Trans Kalimantan) yang merupakan daerah komersial dan jalan minor (jalan Komplek Griya Permata) yang merupakan daerah pemukiman serta merupakan jalan ruas utama yang menghubungkan kota Banjarmasin dengan kotakota disekitarnya seperti Kota Kuala Kapuas, Marabahan, Banjarbaru dan Martapura.

Fenomena "Supeltas (Sukarelawan Pengatur lalulintas)" atau "Polisi Cepek" marak terjadi seiring dengan bertambah panjangnya antrian kendaraan yang terhenti sejenak sebelum berbelok menuju jalan/ arah tertentu. Supeltas sendiri adalah orang (bukan petugas resmi dari pemerintah) yang mengatur lalulintas dengan mengharapkan pemberian sukarela orang-orang yang melintasi jalan tersebut. Keberadaan "Supeltas" yang tidak memiliki pemahaman teori manajemen lalulintas seringkali justru menimbulkan permasalahan lalulintas dan semakin memperparah kemacetan yang ada, dikarenakan Supeltas akan memprioritaskan pergerakan kendaraan yang memberi uang, dengan cara memotong secara berlawanan pergerakan arus lalulintas/ kendaraan lain.

Penelitian terdahulu yang menjadi acuan penelitian ini adalah (1) Supeltas dan Pelican Crossing: Ragam Inovasi Pelayanan Publik di Kota Surakarta, (2) Perencanaan Pengendalian Lalulintas di Persimpangan Jalan Sekitar Jembatan Kuncir Kabupaten Nganjuk Jawa Timur, (3) Analisa Kinerja Simpang Tak Bersinyal pada Ruas Jalan S.Parman dan Jalan di Panjaitan dan (4) Supeltas dan Pelican Crossing: Ragam Inovasi Pelayanan Publik di Kota Surakarta.

Tujuan dari penelitian ini adalah adalah mengetahui nilai kinerja simpang tidak bersinyal akibat pengaruh keberadaan "Supeltas" yang diindikasikan dengan nilai derajat kejenuhan simpang (DS).

Manfaat penelitian ini antara lain (1) Sebagai materi tambahan pembelajaran mengenai kinerja simpang tidak bersinyal untuk mahasiswa bidang transportasi, (2) Sebagai bahan pertimbangan bagi instansi terkait dalam memperbaiki tingkat pelayanan simpang tak bersinyal dan pengambilan keputusan dalam hal pemberdayaan keberadaan Supeltas.

Nilai kapasitas total lengan simpang dapat dihitung dengan persamaan (1) berikut.

$$
C=C_{o} \times F_{W} \times F_{M} \times F_{C S} \times F_{R S U} \times F_{L T} \times F_{R T} \times F_{M I}
$$

Dimana:

$\mathrm{C}=$ Kapasitas Simpang $(\mathrm{smp} / \mathrm{jam})$

$C_{o}=$ Kapasitas Dasar $(\mathrm{smp} / \mathrm{jam})$

$F_{W}=$ Faktor Penyesuaian Lebar Masuk

$F_{M}=$ Faktor Penyesuaian Tipe Median Jalan Utama

$F_{C S}=$ Faktor Penyesuaian Ukuran Kota

$F_{\text {RSU }}=$ Faktor Penyesuaian Tipe Lingkungan Jalan, Hambatan Samping dan Kendaraan Tak Bermotor

$F_{L T} \quad=$ Faktor Penyesuaian Belok Kiri

$F_{R T}=$ Faktor Penyesuaian Belok Kanan

$F_{M I}=$ Faktor Penyesuaian Rasio Arus Jalan Minor 
Nilai-nilai atau koefisien yang dipergunakan untuk perhitungan pada persamaan 1 dapat dilihat pada Tabel I sampai IV berikut.

TABEL I.

Kapasitas Dasar (Co) pada Jalan Luar Kota 2-Jalur 2-Arah Tak-Terbagi (2/2 UD)

\begin{tabular}{cc}
\hline $\begin{array}{c}\text { Tipe jalan/ } \\
\text { Tipe alinyemen }\end{array}$ & $\begin{array}{c}\text { Kapasitas Dasar Total kedua arah } \\
\text { smp/jam }\end{array}$ \\
\hline & \\
\hline Dua-lajur tak-terbagi & \\
- Datar & 3100 \\
- Bukit & 3000 \\
- Gunung & 2900 \\
\hline
\end{tabular}

(Sumber : MKJI 1997)

TABEL II.

Faktor Penyesuaian Kapasitas Akibat Lebar Jalur Lalu lintas $\left(\mathrm{FC}_{\mathrm{W}}\right)$

\begin{tabular}{|c|c|c|}
\hline Tipe Jalan & $\begin{array}{l}\text { Lebar Efektif jalur lalu-lintas }\left(\mathrm{W}_{\mathrm{C}}\right) \\
(\mathrm{m})\end{array}$ & $\mathrm{FC}_{\mathrm{W}}$ \\
\hline \multirow{2}{*}{$\begin{array}{l}\text { Empat-lajur } \\
\text { terbagi }\end{array}$} & Perlajur & \\
\hline & 3,0 & 0,91 \\
\hline \multirow{3}{*}{$\begin{array}{l}\text { Enam-lajur } \\
\text { terbagi }\end{array}$} & 3,25 & 0,96 \\
\hline & 3,5 & 1,00 \\
\hline & 3,75 & 1,03 \\
\hline \multirow{5}{*}{$\begin{array}{l}\text { Empat-lajur tak } \\
\text { terbagi }\end{array}$} & Perlajur & \\
\hline & 3,0 & 0,91 \\
\hline & 3,25 & 0,96 \\
\hline & 3,5 & 1,00 \\
\hline & 3,75 & 1,03 \\
\hline \multirow{7}{*}{$\begin{array}{l}\text { Dua-lajur tak- } \\
\text { terbagi }\end{array}$} & Total kedua arah & \\
\hline & $\frac{5}{6}$ & $\begin{array}{l}0,69 \\
0,91\end{array}$ \\
\hline & $\frac{6}{7}$ & 1,00 \\
\hline & 8 & 1,08 \\
\hline & 9 & 1,15 \\
\hline & 10 & 1,21 \\
\hline & 11 & 1,27 \\
\hline
\end{tabular}

TABEL III.

Faktor Penyesuaian Kapasitas Akibat Pemisahan Arah ( $\left.\mathrm{FC}_{\mathrm{SP}}\right)$

\begin{tabular}{ccccccc}
\hline \multicolumn{2}{l}{ Pemisahan arah SP \%-\% } & $50-50$ & $55-45$ & $60-40$ & $65-35$ & $70-30$ \\
\hline \multirow{2}{*}{$\mathrm{FC}_{\mathrm{SPB}}$} & Dua-lajur 2/2 & 1,00 & 0,97 & 0,94 & 0,91 & 0,88 \\
\cline { 2 - 7 } & Empat-lajur 4/2 & 1,00 & 0,975 & 0,95 & 0,925 & 0,90 \\
\hline (Sumber : & MKJI 1997) & & & & &
\end{tabular}

TABEL IV

Faktor Penyesuaian Kapasitas Akibat Hambatan Samping (FC $\mathrm{FF}$ )

\begin{tabular}{|c|c|c|c|c|c|}
\hline \multirow[t]{3}{*}{$\begin{array}{l}\text { Tipe } \\
\text { Jalan }\end{array}$} & \multirow{3}{*}{$\begin{array}{c}\text { Kelas } \\
\text { hambatan } \\
\text { samping }\end{array}$} & \multicolumn{4}{|c|}{$\begin{array}{l}\text { Faktor penyesuaian akibat } \\
\text { hambatan samping }\left(\mathrm{FC}_{\mathrm{SF}}\right)\end{array}$} \\
\hline & & \multicolumn{4}{|c|}{ Lebar bahu efektif $\mathrm{W}_{\mathrm{S}}$} \\
\hline & & $\leq 0,5$ & 1,0 & 1,5 & $\geq 2,0$ \\
\hline \multirow[t]{5}{*}{$4 / 2 \mathrm{D}$} & VL & 0,99 & 1,00 & 1,01 & 1,03 \\
\hline & $\mathrm{L}$ & 0,96 & 0,97 & 0,99 & 1,01 \\
\hline & $\mathrm{M}$ & 0,93 & 0,96 & 0,96 & 0,99 \\
\hline & $\mathrm{H}$ & 0,90 & 0,92 & 0,95 & 0,97 \\
\hline & VH & 0,88 & 0,90 & 0,93 & 0,96 \\
\hline \multirow[t]{2}{*}{$2 / 2 \mathrm{UD}$} & VL & 0,97 & 0,99 & 1,00 & 1,02 \\
\hline & $\mathrm{L}$ & 0,93 & 0,95 & 0,97 & 1,00 \\
\hline \multirow[t]{3}{*}{$4 / 2 \mathrm{UD}$} & $\mathrm{M}$ & 0,88 & 0,91 & 0,94 & 0,98 \\
\hline & $\mathrm{H}$ & 0,84 & 0,87 & 0,91 & 0,95 \\
\hline & $\mathrm{VH}$ & 0,80 & 0,83 & 0,88 & 0,93 \\
\hline
\end{tabular}

Derajat kejenuhan (DS) sebagai rasio arus terhadap kapasitas, digunakan sebagai faktor utama dalam penentuan perilaku lalulintas pada suatu simpang dan segmen jalan. Nilai derajat kejenuhan (DS) memberikan gambaran apakah segmen jalan tersebut akan mempunyai masalah kapasitas atau tidak.

Sesuai dengan MKJI 1997, perencanaan harus memastikan nilai derajat kejenuhan (DS) lebih besar dari 0,75. Pada Persamaan 2 berikut, dapat dilihat persamaan dasar perhitungan derajat kejenuhan (DS).

$$
D S=Q / C
$$

Dimana:

$D S \quad=$ Derajat Kejenuhan (tanpa satuan)

$Q \quad=$ Volume Arus Lalulintas ( $\mathrm{smp} / \mathrm{jam})$

$C \quad=$ Kapasitas $(\mathrm{smp} / \mathrm{jam})$

Derajat kejenuhan untuk seluruh simpang (DS), dihitung sebagai berikut:

$$
D S=Q_{s m p} / C
$$

Dimana :

$\mathrm{Q}_{\mathrm{smp}}=$ Arus total $(\mathrm{smp} / \mathrm{jam})$,

Dihitung sebagai berikut:

$$
\begin{array}{ll}
\mathrm{Q}_{\text {smp }} & =\text { Qkend } \times \text { Fsmp } \\
\mathrm{F}_{\text {smp }} & =\text { Faktor smp } \\
\mathrm{C} & =\text { Kapasitas }(\mathrm{smp} / \mathrm{jam})
\end{array}
$$

Pada Gambar 1 berikut digambarkan beberapa jenis simpang tidak bersinyal menurut MKJI 1997. 

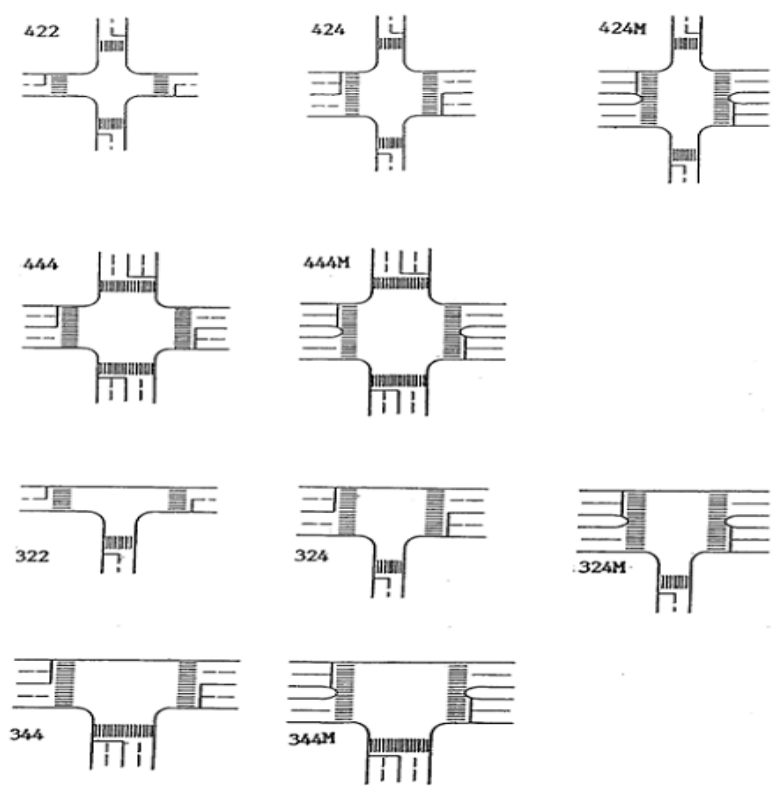

Gambar 1. Berbagai Jenis Tipe Simpang Tak-Bersinyal Menurut MKJI 1997

\section{METODE PENELITIAN}

A. Lokasi Penelitian

Penelitian dilaksanakan pada simpang tiga tidak bersinyal antara Jalan Trans Kalimantan dengan jalan masuk Komplek Griya Permata, Handil Bakti, Kabupaten Barito Kuala, Kalimantan Selatan. Ruas diberi tanda berikut merupakan ketiga lengan jalan yang akan dijadikan lokasi pengambilan data, sesuai dengan Gambar 2 berikut.

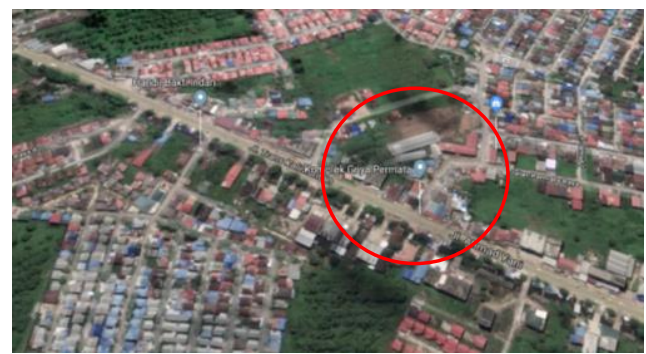

Gambar 2. Lokasi Penelitian di Simpang Tak Bersinyal Jalan Trans Kalimantan-Komplek Griya Permata

\section{B. Instrument Penelitian}

Peralatan yang digunakan adalah alat tulis, handphone android dengan aplikasi traffic counting, pencatat waktu (stop watch), meteran standard dan oddometer, jam tangan sebagai penunjuk waktu selama pelaksanaan survey, laptop sebagai alat bantu perekaman dan processing data.

\section{Prosedur Pengambilan Data}

Data yang diambil adalah data primer yang diambil langsung dengan cara survey langsung di lapangan secara manual pada waktu yang ditentukan dan data sekunder (diperoleh dari referensi lain).

1) Data Primer: Terdiri dari data volume lalulintas yaitu data jumlah pada masing-masing pergerakan kendaraan ringan, kendaraan berat, sepeda motor dan kendaraan tidak bermotor, pada jalan dengan adanya Supeltas dan tanpa Supeltas. Dan data geometrik simpang berupa hasil pengukuran dimensi jalan (gambar lay out simpang, ukuran lebar jalan, lajur dan jalur).

2) Data Sekunder: Data sekunder yang dipergunakan adalah Peta Jalan Luar Kota Banjarmasin menuju Simpang Empat Marabahan Kapuas (Kabupaten Barito Kuala) yang bersumber dari citra Google Map. Dan data sekunder jumlah penduduk Kota Barito Kuala tahun 2016 adalah 302.304 yang diperoleh dari BPS Kabupaten Barito Kuala.

\section{WAKTU SURVEY}

Survey dilaksanakan selama selama dua periode, yaitu untuk survey dengan adanya Supeltas dilaksanakan pada hari Selasa, Rabu dan Kamis (tanggal 11-13 April 2017) dan survey berikutnya dengan meniadakan Supeltas pada hari Selasa, Rabu dan Kamis (tanggal 06-08 Maret 2018) dengan periode waktu selama selama dua jam dengan interval waktu per 15 menit pada setiap waktu puncak, yaitu jam sibuk pagi (jam 06.3008.30 WITA), jam sibuk siang (jam 12.00-14.00 WITA) dan jam sibuk sore (jam 16.30-18.30 WITA).

\section{E. Flow Chard Pelaksanaan Penelitian}

Flowchard pelaksanaan penelitian dapat dilihat pada Gambar 3 berikut. 


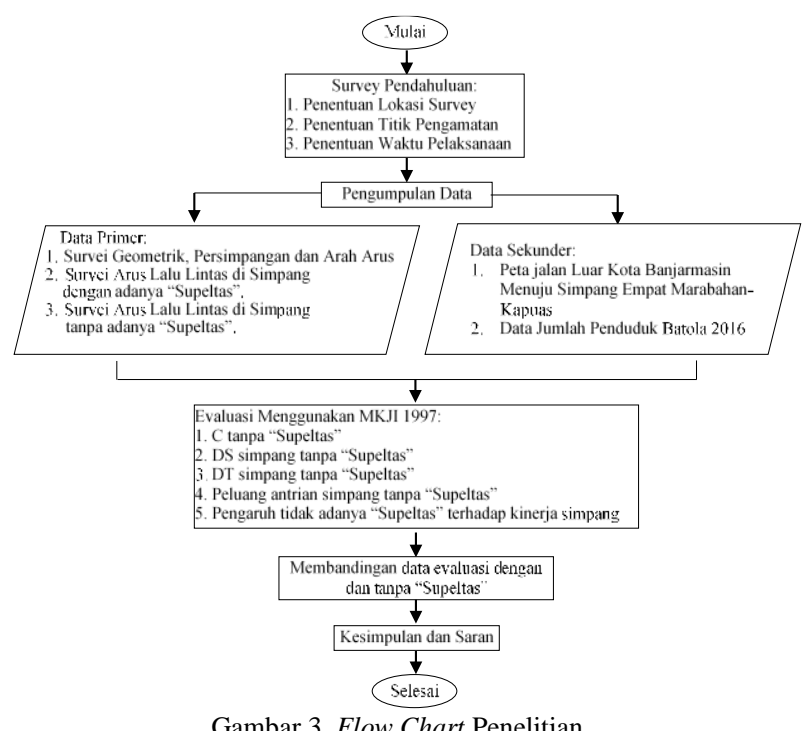

III. HASIL DAN PEMBAHASAN

Berikut adalah hasil perhitungan data lapangan dengan menggunakan pendekatan MKJI 1997.

A. Data Geometrik Jalan Trans KalimantanJalan Komplek Griya Permata

Data geometrik dan arah pergerakan arus lalulintas pada daerah penelitian dapat dilihat pada Gambar 4 berikut.

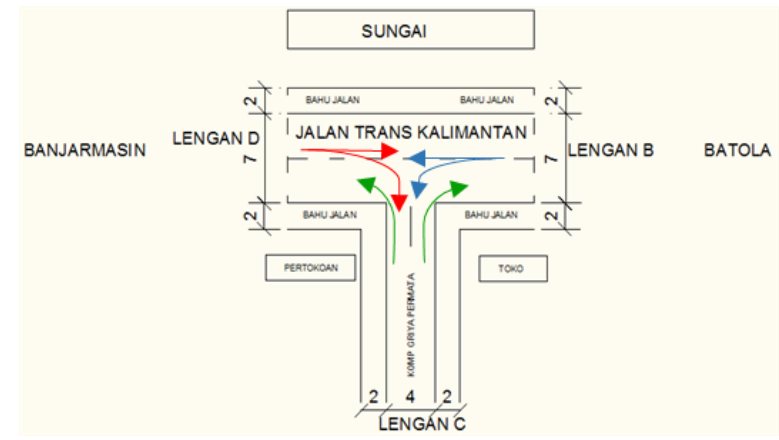

Gambar 4. Kondisi Geometrik dan Arah Pergerakan Arus pada Simpang Tiga Tak Bersinyal pada Jalan Trans Kalimantan-Jalan Komplek Griya Permata

\section{B. Data Arus Lalulintas}

1) Data Hasil Survey Lalulintas dengan Kondisi Adanya "Supeltas": Berikut data survey lalulintas yang diambil pada jam sibuk pagi, siang dan sore pada tanggal 06-09 Maret 2018, yang dapat dilihat pada Tabel V sampai Tabel VIII berikut.
TABEL V

Perhitungan Arus Lalulintas Jam Sibuk

(Hari Selasa, 11 April 2017)

\begin{tabular}{|c|c|c|c|c|c|c|c|c|c|c|}
\hline \multirow{3}{*}{ Waktu } & \multicolumn{8}{|c|}{ Pendekat B (Dari Barito Kuala) } & \multicolumn{2}{|r|}{ Total } \\
\hline & \multicolumn{4}{|c|}{ Lurus } & \multicolumn{4}{|c|}{ Kiri } & \multirow{2}{*}{$\begin{array}{c}\text { Kendaraan } \\
\text { Bermotor }\end{array}$} & \multirow{2}{*}{$\begin{array}{c}\text { Kendaraan Tal } \\
\text { Bermotor }\end{array}$} \\
\hline & $\overline{\mathrm{UM}}$ & $\mathrm{MC}$ & LV & $\mathrm{HV}$ & UM & $\mathrm{MC}$ & LV & $\mathrm{HV}$ & & \\
\hline $06.30-07.30$ & 25 & 3.475 & 209 & 7 & 6 & 156 & 5 & - & 3.852 & 31 \\
\hline $07.30-08.30$ & 8 & 2.549 & 212 & 24 & 3 & 132 & 7 & 2 & 2.926 & 11 \\
\hline $12.00-13.00$ & $\frac{0}{4}$ & 1.169 & 277 & 43 & 2 & 110 & $\frac{1}{6}$ & 1 & 1.606 & $\frac{11}{6}$ \\
\hline $13.00-14.00$ & 3 & 1.167 & 225 & 56 & 1 & 86 & 11 & 2 & 1.547 & 4 \\
\hline $16.30-17.30$ & 9 & 1.418 & 262 & 39 & 3 & 85 & 18 & & 1.822 & 12 \\
\hline $17.30-18.30$ & 9 & 1.301 & 281 & 48 & 7 & 161 & 13 & - & 1.804 & 16 \\
\hline Jumlah & 58 & 11.079 & 1.466 & 217 & 22 & 730 & 60 & 5 & 13.557 & 80 \\
\hline
\end{tabular}

\begin{tabular}{|c|c|c|c|c|c|c|c|c|c|c|}
\hline \multirow{3}{*}{ Waktu } & \multicolumn{8}{|c|}{ 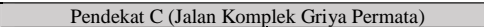 } & \multicolumn{2}{|r|}{ Total } \\
\hline & & $\mathrm{Lu}$ & & & & & & & Kendaraan & Kendaraan Tal \\
\hline & $\overline{\mathrm{UM}}$ & $\mathrm{MC}$ & LV & HV & UM & $\mathrm{MC}$ & LV & HV & Bermotor & Bermotor \\
\hline $06.30-07.30$ & - & 156 & 9 & & 14 & 1.532 & 93 & & 1.790 & 14 \\
\hline $07.30-08.30$ & 5 & 112 & 8 & 1 & 8 & 952 & 60 & 1 & 1.134 & 13 \\
\hline $12.00-13.00$ & 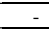 & 92 & 7 & - & 5 & 444 & 31 & 3 & 577 & 5 \\
\hline $13.00-14.00$ & 1 & 70 & 8 & - & 4 & 408 & 49 & 3 & 538 & 5 \\
\hline $16.30-17.30$ & 4 & 156 & 9 & - & 9 & 524 & 30 & - & 719 & 13 \\
\hline $17.30-18.30$ & 2 & 118 & 6 & - & 6 & 350 & 27 & - & 501 & 8 \\
\hline Jumlah & 12 & 704 & 47 & 1 & 46 & 4.210 & 290 & 7 & 5.259 & 58 \\
\hline
\end{tabular}

\begin{tabular}{|c|c|c|c|c|c|c|c|c|c|c|}
\hline \multirow{3}{*}{ Waktu } & \multicolumn{8}{|c|}{ Pendekat D (dari Kota Banjarmasin) } & \multicolumn{2}{|r|}{ Total } \\
\hline & \multicolumn{4}{|c|}{ Lurus } & \multicolumn{4}{|c|}{ Kiri } & \multirow{2}{*}{$\begin{array}{r}\text { Kendaraan } \\
\text { Bermotor }\end{array}$} & \multirow{2}{*}{$\begin{array}{c}\text { Kendaraan Tal } \\
\text { Bermotor }\end{array}$} \\
\hline & $\mathrm{UM}$ & $\mathrm{MC}$ & LV & HV & $\mathrm{UM}$ & $\mathrm{MC}$ & LV & $\mathrm{HV}$ & & \\
\hline $06.30-07.30$ & 13 & 1.272 & 166 & 20 & 7 & 404 & 19 & - & 1.881 & 20 \\
\hline $07.30-08.30$ & 20 & 1.420 & 243 & 28 & 2 & 274 & 11 & - & 1.976 & 22 \\
\hline \begin{tabular}{|l|l}
$12.00-13.00$ \\
\end{tabular} & 10 & 1.143 & 242 & 31 & 4 & 468 & 35 & - & 1.919 & 14 \\
\hline $13.00-14.00$ & 12 & 1.207 & 230 & 38 & 8 & 450 & 27 & 1 & 1.953 & 20 \\
\hline \begin{tabular}{|l}
$16.30-17.30$ \\
\end{tabular} & 20 & 2.531 & 282 & 42 & 4 & 937 & 79 & - & 3.871 & 24 \\
\hline \begin{tabular}{|l}
$17.30-18.30$ \\
\end{tabular} & 10 & 2.275 & 279 & 47 & 5 & 852 & 71 & 1 & 3.525 & 15 \\
\hline Jumlah & 85 & 9.848 & 1.442 & 206 & 30 & 3.385 & 242 & 2 & 15.125 & 115 \\
\hline
\end{tabular}

TABEL VI

Perhitungan Arus Lalulintas Jam Sibuk

(Hari Rabu, 12 April 2017)

\begin{tabular}{|c|c|c|c|c|c|c|c|c|c|c|}
\hline \multirow{3}{*}{ Waktu } & \multicolumn{8}{|c|}{ Pendekat B (Dari Barito Kuala) } & \multicolumn{2}{|r|}{ Total } \\
\hline & \multicolumn{4}{|c|}{ Lurus } & \multicolumn{4}{|c|}{ Kiri } & Kendaraan & Kendaraan Tak \\
\hline & $\overline{\mathrm{UM}}$ & $\mathrm{MC}$ & LV & $\mathrm{HV}$ & UM & $\mathrm{MC}$ & $\mathrm{LV}$ & $\mathrm{HV}$ & Bermotor & Bermotor \\
\hline \begin{tabular}{|l|}
$06.30-07.30$ \\
\end{tabular} & 25 & 3.350 & 227 & 9 & 5 & 84 & 1 & - & 3.671 & 30 \\
\hline \begin{tabular}{|l|}
$07.30-08.30$ \\
\end{tabular} & 15 & 2.485 & 202 & 34 & 1 & 119 & 3 & - & 2.843 & 16 \\
\hline $12.00-13.00$ & 8 & 1.160 & 259 & 49 & 1 & 96 & 11 & - & 1.575 & 9 \\
\hline \begin{tabular}{|l|}
$13.00-14.00$ \\
\end{tabular} & 3 & 1.382 & 294 & 53 & 2 & 95 & 14 & - & 1.838 & 5 \\
\hline \begin{tabular}{|l|}
$16.30-17.30$ \\
\end{tabular} & 13 & 941 & 300 & 47 & 4 & 101 & 13 & 1 & 1.403 & 17 \\
\hline \begin{tabular}{|l|}
$17.30-18.30$ \\
\end{tabular} & 4 & 782 & 252 & 49 & 7 & 109 & 72 & 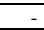 & 1.264 & 11 \\
\hline Jumlah & 68 & 10.100 & 1.534 & 241 & 20 & 604 & 114 & 1 & 12.594 & 88 \\
\hline
\end{tabular}

\begin{tabular}{|c|c|c|c|c|c|c|c|c|c|c|}
\hline \multirow{3}{*}{ Waktu } & \multicolumn{8}{|c|}{ Pendekat C (Jalan Komplek Griya Permata) } & \multicolumn{2}{|r|}{ Total } \\
\hline & \multicolumn{4}{|c|}{ Lurus } & \multicolumn{4}{|c|}{ Kiri } & \multirow{2}{*}{$\begin{array}{r}\text { Kendaraan } \\
\text { Bermotor }\end{array}$} & \multirow{2}{*}{$\begin{array}{c}\text { Kendaraan Tak } \\
\text { Bermotor }\end{array}$} \\
\hline & $\overline{\mathrm{UM}}$ & $\mathrm{MC}$ & LV & $\mathrm{HV}$ & UM & $\mathrm{MC}$ & $\mathrm{LV}$ & $\mathrm{HV}$ & & \\
\hline $06.30-07.30$ & 1 & 115 & 11 & 1 & 9 & 1.429 & 69 & & 1.625 & 10 \\
\hline $07.30-08.30$ & 3 & 152 & 12 & 2 & 9 & 922 & 38 & 2 & 1.128 & 12 \\
\hline $12.00-13.00$ & - & 87 & 10 & 1 & 7 & 387 & 36 & 1 & 522 & 7 \\
\hline $13.00-14.00$ & 2 & 94 & 12 & 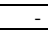 & 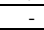 & 400 & 26 & 2 & 534 & 2 \\
\hline $16.30-17.30$ & 4 & 135 & 9 & - & 7 & 333 & 47 & - & 524 & 11 \\
\hline $17.30-18.30$ & - & 97 & 14 & - & 4 & 111 & 21 & - & 243 & 4 \\
\hline Jumlah & 10 & 680 & 68 & 4 & 36 & 3.582 & 237 & 5 & 4.576 & 46 \\
\hline
\end{tabular}

\begin{tabular}{|c|c|c|c|c|c|c|c|c|c|c|}
\hline \multirow{3}{*}{ Waktu } & \multicolumn{8}{|c|}{ Pendekat D (dari Kota Banjarmasin) } & \multicolumn{2}{|r|}{ Total } \\
\hline & \multicolumn{4}{|c|}{ Lurus } & \multicolumn{4}{|c|}{ Kiri } & \multirow{2}{*}{\multicolumn{2}{|c|}{$\begin{array}{l}\text { Kendaraan } \text { Kendaraan Tal } \\
\text { Bermotor } \quad \text { Bermotor }\end{array}$}} \\
\hline & $\mathrm{UM}$ & $\mathrm{MC}$ & LV & HV & UM & $\mathrm{MC}$ & LV & HV & & \\
\hline $06.30-07.30$ & 19 & 1.382 & 149 & 21 & 9 & 458 & 18 & 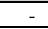 & 2.028 & 28 \\
\hline $07.30-08.30$ & 20 & 1. & 253 & 32 & 6 & 4 & 23 & 1 & 369 & 6 \\
\hline & 9 & & 237 & 41 & 10 & & 40 & & 35 & 19 \\
\hline $13.00-14.00$ & 7 & 1.2 & 310 & 45 & 2 & 520 & 36 & 3 & 2.117 & 9 \\
\hline $16.30-17.30$ & 20 & 2.5 & 282 & 42 & 4 & 937 & 79 & & 3.871 & 24 \\
\hline $17.30-$ & 10 & & 279 & 47 & 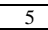 & 852 & 71 & & 3.525 & 15 \\
\hline Jumlah & 85 & 10.112 & 1.510 & 228 & 36 & 3.671 & 267 & 7 & 15.795 & 121 \\
\hline
\end{tabular}


TABEL VII

Perhitungan Arus Lalulintas Jam Sibuk (Hari Kamis, 13 April 2017)

\begin{tabular}{|lrrrrrrrrrrrr|}
\hline \multirow{3}{*}{ Waktu } & \multicolumn{1}{c|}{ Pendekat B (Dari Barito Kuala) } \\
\cline { 2 - 14 } & \multicolumn{4}{c}{ Lurus } & \multicolumn{4}{c|}{ Kiri } & \multicolumn{4}{c|}{ Tondaraan } \\
& UM & MC & LV & HV & UM & MC & LV & HV & Bermotoran Tak & Bermotor \\
\hline $06.30-07.30$ & 25 & 3.048 & 223 & 12 & 7 & 121 & 10 & - & 3.414 & 32 \\
\hline $07.30-08.30$ & 12 & 2.491 & 226 & 12 & 2 & 102 & 3 & - & 2.834 & 14 \\
\hline $12.00-13.00$ & 2 & 1.100 & 277 & 46 & 4 & 132 & 4 & - & 1.559 & 6 \\
\hline $13.00-14.00$ & 4 & 1.311 & 316 & 58 & - & 92 & 8 & 1 & 1.786 & 4 \\
\hline $16.30-17.30$ & 16 & 1.553 & 348 & 47 & 7 & 186 & 17 & 1 & 2.152 & 23 \\
\hline $17.30-18.30$ & 14 & 1.641 & 336 & 59 & 4 & 147 & 12 & - & 2.195 & 18 \\
\hline Jumlah & 73 & 11.144 & 1.726 & 234 & 24 & 780 & 54 & 2 & 13.940 & 97 \\
\hline
\end{tabular}

\begin{tabular}{|c|c|c|c|c|c|c|c|c|c|c|}
\hline \multirow{3}{*}{ Waktu } & \multicolumn{8}{|c|}{$\begin{array}{l}\text { Pendekat C (Jalan Komplek Griya Permata) } \\
\text {. }\end{array}$} & \multicolumn{2}{|r|}{ Total } \\
\hline & \multicolumn{4}{|c|}{ Lurus } & \multicolumn{4}{|c|}{ Kiri } & \multirow{2}{*}{$\begin{array}{c}\text { Kendaraan } \\
\text { Bermotor }\end{array}$} & \multirow{2}{*}{$\begin{array}{c}\text { Kendaraan Tak } \\
\text { Bermotor }\end{array}$} \\
\hline & $\mathrm{UM}$ & $\mathrm{MC}$ & LV & $\mathrm{HV}$ & UM & MC & LV & $\mathrm{HV}$ & & \\
\hline $06.30-07.30$ & 5 & 140 & 11 & & 15 & 1.341 & 53 & - & 1.545 & 20 \\
\hline$\overline{07.30-(-6}$ & 1 & 160 & 10 & 1 & 12 & 894 & 48 & - & 1.113 & 13 \\
\hline $12.00-1$ & 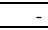 & 108 & 8 & 2 & 4 & 428 & 40 & 1 & 587 & 4 \\
\hline $13.00-$ & - & & 4 & 3 & 7 & 552 & & - & 696 & 7 \\
\hline $16.30-17.30$ & 1 & 184 & 9 & 1 & 10 & 522 & 50 & 2 & 768 & 11 \\
\hline $7.30-18.30$ & - & 18 & 8 & & 2 & 530 & 49 & 1 & 776 & 2 \\
\hline Jumlah & 7 & 882 & 50 & 7 & 50 & 4.267 & 275 & 4 & 5.485 & 57 \\
\hline
\end{tabular}

\begin{tabular}{|c|c|c|c|c|c|c|c|c|c|c|}
\hline \multirow{3}{*}{ Waktu } & \multicolumn{8}{|c|}{ Pendekat D (dari Kota Banjarmasin) } & \multicolumn{2}{|r|}{ Total } \\
\hline & & & & & & $\mathrm{K}$ & & & Kendaraan & Kendaraan Tak \\
\hline & $\overline{\mathrm{UM}}$ & $\mathrm{MC}$ & LV & $\mathrm{HV}$ & UM & $\mathrm{MC}$ & LV & HV & Bermotor & Bermotor \\
\hline $06.30-07.30$ & 17 & 1.286 & 147 & 27 & 11 & 436 & 14 & 1 & 1.911 & 28 \\
\hline $07.30-08.30$ & 22 & 1.617 & 247 & 18 & 5 & 362 & 32 & - & 2.276 & 27 \\
\hline $12.00-13.00$ & 12 & 1.279 & 263 & 54 & 2 & 473 & 38 & 2 & 2.109 & 14 \\
\hline $13.00-14.00$ & 11 & 1.465 & 326 & 53 & 5 & 538 & 49 & 1 & 2.432 & 16 \\
\hline $16.30-17.30$ & 25 & 2.224 & 339 & 46 & 13 & 839 & 67 & 1 & 3.516 & 3 \\
\hline $17.30-18.30$ & 8 & 2.266 & 293 & 47 & 4 & 970 & 80 & 1 & 3.657 & 12 \\
\hline
\end{tabular}

Pada Tabel VIII berikut, dapat dilihat data hasil survei pada Pendekat B paling padat yang digunakan untuk perhitungan adalah data survey pada hari Selasa, 11 April 2017, jam sibuk pagi pukul 06.30-07.30 WITA.

TABEL VIII

Data Hasil Survei yang Digunakan untuk Perhitungan

\begin{tabular}{|c|c|c|c|c|c|c|c|c|}
\hline \multirow{3}{*}{ Lengan } & \multirow{3}{*}{$\begin{array}{l}\text { Arah } \\
\text { Pergerakan }\end{array}$} & \multicolumn{7}{|c|}{ Jenis Kendaraan } \\
\hline & & \multirow{2}{*}{\multicolumn{2}{|c|}{$\begin{array}{c}\text { HV (EMP : } 1,3 \text { ) } \\
\text { Kend/ jam SMP/ jam K }\end{array}$}} & \multirow{2}{*}{\multicolumn{2}{|c|}{$\begin{array}{l}\text { LV (EMP : 1,3) } \\
\text { Kend/ jam SMP/ jam }\end{array}$}} & \multicolumn{2}{|c|}{ MC (EMP : 0,5$)$} & \multirow[b]{2}{*}{ UM } \\
\hline & & & & & & Kend/ jam & SMP/jam & \\
\hline \multirow{2}{*}{$\begin{array}{l}\text { Jl. Trans Kalimantan (MRB) } \\
\text { (Pendekat B) }\end{array}$} & Lurus & 7 & 9,1 & 209 & 209 & 3.475 & $1.737,5$ & 25 \\
\hline & Kiri & 0 & 0,0 & 5 & 5 & 156 & 78 & 6 \\
\hline \multirow{2}{*}{$\begin{array}{l}\text { Jl. Komp Griya Permata } \\
\text { (Pendekat C) }\end{array}$} & Kanan & 0 & 0,0 & 9 & 9 & 156 & 78 & 0 \\
\hline & Kiri & 0 & 0,0 & 93 & 93 & 1.532 & 766 & 14 \\
\hline \multirow{2}{*}{$\begin{array}{l}\text { Jl. Trans Kalimantan (BJM) } \\
\text { (Pendekat D) }\end{array}$} & Lurus & 20 & 26,0 & 166 & 166 & 1.272 & 636 & 13 \\
\hline & Kanan & 0 & 0,0 & 19 & 19 & 404 & 202 & 7 \\
\hline \multirow[t]{4}{*}{ Jumlah } & & 27 & 35,1 & 501 & 501 & 6.995 & $3.497,5$ & 65 \\
\hline & Total Ke & endaraan B & motor (Ke & end/ jam) & $=7.523,0$ & & & \\
\hline & Total Satuan & n Mobil Penu & mpang $\left(\mathrm{S}_{\mathrm{S}}\right.$ & $\mathrm{mp} / \mathrm{jam}$ ) & $=4.033,6$ & & & \\
\hline & & Total Kenda & aan Tak E & Bermotor & 65,0 & & & \\
\hline
\end{tabular}

2) Data Arus Lalulintas pada Kondisi Tanpa Adanya Supeltas: Berikut merupakan data perhitungan arus lalulintas yang diambil pada jam sibuk pagi, jam sibuk siang dan jam sibuk sore pada tanggal 06-08 Maret 2018, yang dapat dilihat pada Tabel IX sampai Tabel XII berikut.
TABEL IX

Perhitungan Arus Lalulintas Jam Sibuk (Hari Selasa, 06 Maret 2018)

\begin{tabular}{|crrrrrrrrrrrr|}
\hline \multirow{3}{*}{ Waktu } & \multicolumn{1}{c|}{ Pendekat B (Dari Barito Kuala) } \\
\cline { 2 - 12 } & \multicolumn{1}{c|}{ Lurus } & \multicolumn{4}{c|}{ Kiri } & \multicolumn{4}{c|}{ Total } \\
& UM & MC & LV & HV & UM & MC & LV & HV & Bermotor & $\begin{array}{c}\text { Kendaraan Tak } \\
\text { Bermotor }\end{array}$ \\
\hline $06.30-07.30$ & 12 & 3.451 & 198 & 9 & 8 & 145 & 6 & - & 3.809 & 20 \\
\hline $07.30-08.30$ & 7 & 4.059 & 205 & 14 & 3 & 175 & 11 & - & 4.464 & 10 \\
\hline $12.00-13.00$ & 6 & 1.104 & 267 & 54 & 1 & 114 & 13 & 1 & 1.553 & 7 \\
\hline $13.00-14.00$ & 2 & 1.055 & 312 & 50 & - & 102 & 14 & - & 1.533 & 2 \\
\hline $16.30-17.30$ & 3 & 1.139 & 276 & 60 & - & 159 & 10 & 2 & 1.646 & 13 \\
\hline $17.30-18.30$ & 8 & 1.218 & 309 & 33 & 1 & 236 & 28 & - & 1.824 & 9 \\
\hline Jumlah & 48 & 12.026 & 1.567 & 220 & 13 & 931 & 82 & 3 & 14.829 & 61 \\
\hline
\end{tabular}

\begin{tabular}{|c|c|c|c|c|c|c|c|c|c|c|}
\hline \multirow{3}{*}{ Waktu } & \multicolumn{8}{|c|}{ 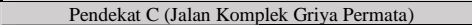 } & \multicolumn{2}{|r|}{ Total } \\
\hline & \multicolumn{4}{|c|}{ Lurus } & \multicolumn{4}{|c|}{ Kiri } & \multirow{2}{*}{$\begin{array}{l}\text { Kendaraan } \\
\text { Bermotor }\end{array}$} & \multirow{2}{*}{$\begin{array}{c}\text { Kendaraan Tak } \\
\text { Bermotor }\end{array}$} \\
\hline & $\overline{\mathrm{UM}}$ & $\mathrm{MC}$ & LV & $\mathrm{HV}$ & $\mathrm{UM}$ & $\mathrm{MC}$ & $\mathrm{LV}$ & $\mathrm{HV}$ & & \\
\hline $06.30-07.30$ & 2 & 189 & 9 & 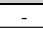 & 26 & 90 & 84 & - & 372 & 28 \\
\hline $07.30-08.30$ & 1 & 209 & 17 & 2 & 3 & 1.401 & 59 & 2 & 1.690 & 4 \\
\hline $12.00-13.00$ & 2 & 206 & 9 & 5 & 4 & 296 & 34 & 2 & 552 & 6 \\
\hline $13.00-14.00$ & 6 & 126 & 10 & 1 & 9 & 416 & 32 & 1 & 586 & 15 \\
\hline $16.30-17.30$ & 2 & 166 & 7 & 1 & 9 & 349 & 33 & 3 & 559 & 11 \\
\hline $17.30-18.30$ & 1 & 227 & 15 & 1 & 3 & 367 & 40 & 1 & 651 & 4 \\
\hline Jumlah & 14 & 1.123 & 67 & 10 & 54 & 2.919 & 282 & 9 & 4.410 & 68 \\
\hline
\end{tabular}

\begin{tabular}{|c|c|c|c|c|c|c|c|c|c|c|}
\hline \multirow{3}{*}{ Waktu } & \multicolumn{8}{|c|}{ Pendekat D (dari Kota Banjarmasin) } & \multicolumn{2}{|r|}{ Total } \\
\hline & & $\mathrm{Lu}$ & & & & & & & Kendaraan & Kendaraan Tak \\
\hline & $\mathrm{UM}$ & MC & LV & $\mathrm{HV}$ & $\mathrm{UM}$ & MC & LV & HV & Bermotor & Bermotor \\
\hline $06.30-07.30$ & 10 & 959 & 127 & 19 & 10 & 286 & 16 & - & 1.407 & 20 \\
\hline $07.30-08.30$ & 18 & 1.657 & 239 & 10 & 2 & 135 & 24 & - & 2.065 & 20 \\
\hline $12.00-13.00$ & 6 & 1.339 & 299 & 43 & - & 458 & 49 & 1 & 2.189 & 6 \\
\hline $13.00-14.00$ & 17 & 1.332 & 240 & 50 & 5 & 457 & 46 & 2 & 2.127 & 22 \\
\hline \begin{tabular}{|l|}
$16.30-17.30$ \\
\end{tabular} & 15 & 2.107 & 269 & 31 & 1 & 795 & 52 & 2 & 3.256 & 16 \\
\hline $17.30-18.30$ & 11 & 2.459 & 348 & 50 & 2 & 883 & 195 & 2 & 3.937 & 13 \\
\hline Jumlah & 77 & 9.853 & 1.522 & 203 & 20 & 3.014 & 382 & 7 & 14.981 & 97 \\
\hline
\end{tabular}

TABEL $\mathrm{X}$

Perhitungan Arus Lalulintas Jam Sibuk (Hari Rabu, 07 Maret 2018)

\begin{tabular}{|c|c|c|c|c|c|c|c|c|c|c|}
\hline \multirow{3}{*}{ Waktu } & \multicolumn{8}{|c|}{ Pendekat B (Dari Barito Kuala) } & \multicolumn{2}{|r|}{ Total } \\
\hline & \multicolumn{4}{|c|}{ Lurus } & \multicolumn{4}{|c|}{ Kiri } & Kendaraan & Kendaraan Tak \\
\hline & $\overline{\mathrm{UM}}$ & $\mathrm{MC}$ & LV & $\mathrm{HV}$ & UM & $\mathrm{MC}$ & LV & $\mathrm{HV}$ & Bermotor & Bermotor \\
\hline $06.30-07.30$ & 17 & 3.917 & 205 & 8 & 4 & 101 & - & - & 4.231 & 21 \\
\hline $07.30-08.30$ & 12 & 3.331 & 233 & 28 & - & 101 & 3 & - & 3.696 & 12 \\
\hline $12.00-13.00$ & - & 1.286 & 316 & 69 & - & 120 & 7 & 1 & 1.799 & 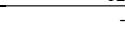 \\
\hline $13.00-14.00$ & - & 1.176 & 329 & 70 & - & 94 & 15 & 7 & 1.691 & - \\
\hline $16.30-17.30$ & - & 1.697 & 276 & 60 & - & 188 & 11 & 1 & 2.233 & 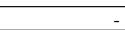 \\
\hline $17.30-18.30$ & 8 & 1.931 & 287 & 55 & - & 141 & 18 & 3 & 2.435 & 8 \\
\hline Jumlah & 37 & 13.338 & 1.646 & 290 & 4 & 745 & 54 & 12 & 16.085 & 41 \\
\hline \multirow{3}{*}{ Waktu } & \multicolumn{8}{|c|}{ Pendekat C (Jalan Komplek Griya Permata) } & \multicolumn{2}{|r|}{ Total } \\
\hline & \multicolumn{4}{|c|}{ Lurus } & \multicolumn{4}{|c|}{ Kiri } & \multirow{2}{*}{\multicolumn{2}{|c|}{$\begin{array}{c}\text { Kendaraan } \\
\text { Bendaraan Tak } \\
\text { Bermotor } \\
\text { Bermotor }\end{array}$}} \\
\hline & $\mathrm{UM}$ & $\mathrm{MC}$ & LV & HV & UM & $\mathrm{MC}$ & LV & HV & & \\
\hline $06.30-07.30$ & 2 & 226 & 7 & 2 & 17 & 1.608 & 94 & - & 1.937 & 19 \\
\hline $07.30-08.30$ & 1 & 208 & 18 & - & 5 & 1.096 & 78 & - & 1.400 & 6 \\
\hline $12.00-13.00$ & 2 & 104 & 20 & 10 & 1 & 377 & 31 & 1 & 543 & 3 \\
\hline $13.00-14.00$ & - & 43 & 2 & - & 2 & 252 & 32 & - & 329 & 2 \\
\hline $16.30-17.30$ & - & 149 & 5 & - & 5 & 429 & 40 & 2 & 625 & 5 \\
\hline $17.30-18.30$ & - & 189 & 4 & 4 & 4 & 459 & 44 & 1 & 701 & 4 \\
\hline Jumlah & 5 & 919 & 56 & 16 & 34 & 4.221 & 319 & 4 & 5.535 & 39 \\
\hline \multirow{3}{*}{ Waktu } & \multicolumn{8}{|c|}{ Pendekat D (dari Kota Banjarmasin) } & \multicolumn{2}{|r|}{ Total } \\
\hline & & Lur & & & & & & & Kendaraan & Kendaraan Tak \\
\hline & $\overline{\mathrm{UM}}$ & $\mathrm{MC}$ & LV & HV & UM & MC & LV & $\mathrm{HV}$ & Bermotor & Bermotor \\
\hline $06.30-07.30$ & - & 860 & 77 & 19 & 9 & 455 & 16 & 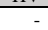 & 1.427 & 9 \\
\hline $07.30-08.30$ & - & 1.253 & 205 & 22 & 7 & 457 & 11 & 1 & 1.949 & 7 \\
\hline $12.00-13.00$ & - & 1.229 & 294 & 50 & 10 & 518 & 40 & - & 2.131 & 10 \\
\hline $13.00-14.00$ & - & 733 & 213 & 24 & 3 & 350 & 53 & - & 1.373 & 3 \\
\hline $16.30-17.30$ & - & 1.808 & 277 & 49 & 3 & 834 & 69 & 1 & 3.038 & 3 \\
\hline $17.30-18.30$ & - & 1.782 & 238 & 39 & 5 & 1.009 & 19 & 3 & 3.090 & 5 \\
\hline Jumlah & 0 & 7665 & 1304 & 203 & 37 & 3623 & 208 & 5 & 13008 & 37 \\
\hline
\end{tabular}


TABEL XI

Perhitungan Arus Lalulintas Jam Sibuk (Hari Kamis, 08 Maret 2018)

\begin{tabular}{|c|c|c|c|c|c|c|c|c|c|c|}
\hline \multirow{3}{*}{ Waktu } & \multicolumn{8}{|c|}{ Pendekat B (Dari Barito Kuala) } & \multicolumn{2}{|r|}{ Total } \\
\hline & \multicolumn{4}{|c|}{ Lurus } & \multicolumn{4}{|c|}{ Kiri } & Kendaraan & Kendaraan Tak \\
\hline & $\overline{\mathrm{UM}}$ & MC & LV & $\mathrm{HV}$ & UM & $\mathrm{MC}$ & LV & HV & Bermotor & Bermotor \\
\hline $06.30-07.30$ & 16 & 4.307 & 235 & 16 & 8 & 109 & 5 & - & 4.672 & 24 \\
\hline $07.30-08.30$ & 11 & 2.512 & 186 & 34 & 4 & 122 & 1 & - & 2.855 & 15 \\
\hline $12.00-13.00$ & 2 & 1.108 & 223 & 44 & - & 117 & 5 & 4 & 1.501 & 2 \\
\hline $13.00-14.00$ & 7 & 1.196 & 300 & 38 & - & 115 & 7 & 1 & 1.657 & 7 \\
\hline $16.30-17.30$ & 9 & 1.494 & 288 & 5 & 1 & 224 & 19 & - & 2.030 & 10 \\
\hline $17.30-18.30$ & 5 & 1.430 & 255 & 6 & - & 187 & 14 & - & 1.892 & 5 \\
\hline \begin{tabular}{|l|} 
Jumlah \\
\end{tabular} & 50 & 12.047 & 1.487 & 143 & 13 & 874 & 51 & 5 & 14.607 & 63 \\
\hline \multirow{3}{*}{ Waktu } & \multicolumn{8}{|c|}{ Pendekat C (Jalan Komplek Griya Permata) } & \multicolumn{2}{|r|}{ Total } \\
\hline & \multicolumn{4}{|c|}{ Lurus } & \multicolumn{4}{|c|}{ Kiri } & \multirow{2}{*}{\multicolumn{2}{|c|}{$\begin{array}{cc}\text { Kendaraan } & \text { Kendaraan Tak } \\
\text { Bermotor } & \text { Bermotor }\end{array}$}} \\
\hline & $\mathrm{UM}$ & MC & LV & $\mathrm{HV}$ & UM & $\mathrm{MC}$ & LV & $\mathrm{HV}$ & & \\
\hline $06.30-07.30$ & - & 220 & 15 & 1 & 22 & 1.970 & 90 & - & 2.296 & 22 \\
\hline $07.30-08.30$ & 1 & 207 & 16 & 1 & 5 & 1.022 & 52 & 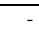 & 1.298 & 6 \\
\hline $12.00-13.00$ & 3 & 91 & 10 & - & 8 & 314 & 45 & 8 & 468 & 11 \\
\hline $13.00-14.00$ & - & 136 & 8 & - & - & 519 & 53 & 1 & 717 & - \\
\hline $16.30-17.30$ & - & 351 & 19 & - & 1 & 595 & 57 & - & 1.022 & 1 \\
\hline $17.30-18.30$ & - & 223 & 14 & - & 1 & 774 & 81 & - & 1.092 & 1 \\
\hline Jumlah & 4 & 1.228 & 82 & 2 & 37 & 5.194 & 378 & 9 & 6.893 & 41 \\
\hline
\end{tabular}

\begin{tabular}{|c|c|c|c|c|c|c|c|c|c|c|}
\hline \multirow{3}{*}{ Waktu } & \multicolumn{8}{|c|}{ Pendekat D (dari Kota Banjarmasin) } & \multicolumn{2}{|r|}{ Total } \\
\hline & \multicolumn{4}{|c|}{ Lurus } & \multicolumn{4}{|c|}{ Kiri } & \multirow{2}{*}{$\begin{array}{r}\text { Kendaraan } \\
\text { Bermotor }\end{array}$} & \multirow{2}{*}{$\begin{array}{c}\text { Kendaraan Tak } \\
\text { Bermotor }\end{array}$} \\
\hline & UM & $\mathrm{MC}$ & LV & $\mathrm{HV}$ & UM & $\mathrm{MC}$ & LV & $\mathrm{HV}$ & & \\
\hline $06.30-07.30$ & 8 & 1.414 & 120 & 12 & 11 & 471 & 17 & 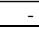 & 2.034 & 19 \\
\hline $07.30-08.30$ & 10 & 1.704 & 219 & 21 & 5 & 438 & 34 & - & 2.416 & 15 \\
\hline $12.00-13.00$ & - & 1.309 & 311 & 82 & 4 & 482 & 41 & 2 & 2.227 & 4 \\
\hline \begin{tabular}{|l|}
$13.00-14.00$ \\
\end{tabular} & 18 & 1.306 & 253 & 45 & 5 & 484 & 34 & 1 & 2.123 & 23 \\
\hline $16.30-17.30$ & 15 & 2.585 & 288 & 51 & 4 & 833 & 63 & 1 & 3.821 & 19 \\
\hline $17.30-18.30$ & 13 & 3.238 & 263 & 43 & 1 & 750 & 76 & 1 & 4.371 & 14 \\
\hline Jumlah & 64 & 11.556 & 1.454 & 254 & 30 & 3.458 & 265 & 5 & 16.992 & 94 \\
\hline
\end{tabular}

Data hasil survei digunakan untuk perhitungan adalah data hari Kamis, 08 Maret 2018 jam sibuk pagi pukul 06.30-07.30 WITA pada Pendekat B yang paling padat dapat dilihat pada Tabel XII berikut.

\section{TABEL XII}

Data Hasil Survei yang Digunakan untuk Perhitungan.

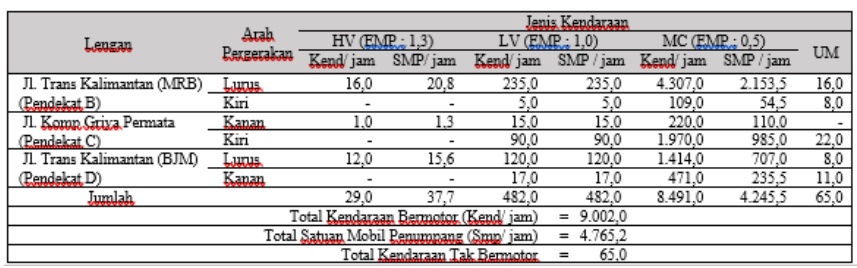

\section{F. Pembahasan}

Adapun pembahasan yang akan dilakukan dalam penelitian ini adalah mengetahui dampak aktivitas Supeltas terhadap kinerja ruas Jalan Trans Kalimantan - Jalan Komplek Griya Permata yang ditunjukkan dengan nilai DS (derajat kejenuhan) dan tingkat pelayanan jalannya dapat dilihat pada Tabel XIII sampai Tabel XVIII berikut.
TABEL XIII

Formulir USIG I dengan Kondisi Adanya Supeltas

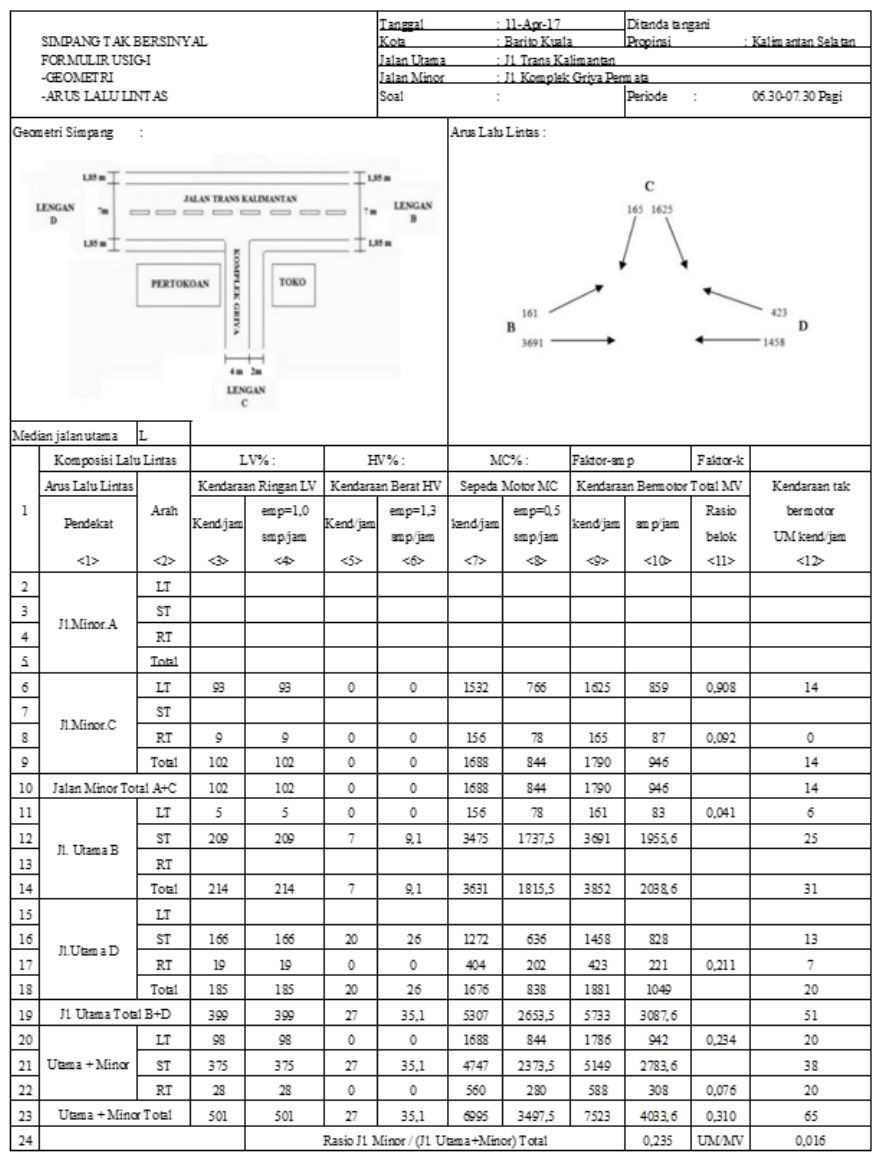

TABEL XIV

Formulir USIG II dengan Kondisi Adanya Supeltas (Tahun 2017)

\begin{tabular}{|c|c|c|c|c|c|c|c|c|c|c|c|}
\hline \multirow{5}{*}{\multicolumn{2}{|c|}{$\begin{array}{l}\text { SIMPANG TAK BERSNYY } \\
\text { PORMUIR USGG-II } \\
\text { - ANALISA }\end{array}$}} & & & & & & \multicolumn{2}{|c|}{ 11-Ax-17 } & \multicolumn{3}{|c|}{ Ditangani olkh } \\
\hline & & & & & & & \multicolumn{2}{|c|}{ Bariemasin } & \multicolumn{2}{|c|}{ Uhuran koda } & $298.282 \mathrm{ims}$ \\
\hline & & & & & & \multicolumn{2}{|c|}{ IL Trans Kalmantan } & \multicolumn{2}{|c|}{ Einglungen jalan } & Pemukiman \\
\hline & & & & & \multicolumn{2}{|c|}{ Jalan Minor } & \multicolumn{2}{|c|}{ IL Koplek Griy Prmata } & \multicolumn{2}{|c|}{ Hambatan smping } & Ingeg \\
\hline & & & & & \multicolumn{4}{|l|}{ Soal } & \multicolumn{2}{|l|}{ Periode } & $06.30-07.00$ \\
\hline \multicolumn{12}{|c|}{ 1. Labar Pendelatat dan Tipe Simparg } \\
\hline \multirow{4}{*}{ Pithan } & \multirow{3}{*}{ Jumlah Lengan } & \multicolumn{7}{|c|}{ Leber Pendelkat $<m\rangle$} & \multirow{2}{*}{\multicolumn{2}{|c|}{$\begin{array}{l}\text { Jumlah lajur } \\
\text { Gamber } B-12\end{array}$}} & \multirow{3}{*}{\begin{tabular}{|c|} 
Tipe \\
Simpang \\
Tal B-1:1
\end{tabular}} \\
\hline & & & $\operatorname{Jaln} M$ & & & an Utart & & & & & \\
\hline & & WA & wc & WAC & wB & WD & WBD & \multirow{2}{*}{$\begin{array}{c}\text { Pendelatat } \\
\text { Rata-rata WI } \\
\&\end{array}$} & $\begin{array}{l}\text { Jalan } \\
\text { naro }\end{array}$ & Jalin & \\
\hline & $\triangleleft>$ & $\phi$ & $\Leftrightarrow$ & $\langle 4\rangle$ & $\Leftrightarrow$ & $\infty$ & $\Leftrightarrow$ & & $\theta$ & $<10>$ & $41>$ \\
\hline 1 & 322 & 0 & 2 & 4 & 3,5 & 3,5 & 3,5 & 3,000 & 2 & 2 & 322 \\
\hline 2 & 322 & - & 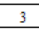 & 3 & 5,25 & 5,25 & 5,25 & 4,500 & 2 & 2 & 322 \\
\hline 3 & 322 & 0 & 3 & 3 & 4,75 & 4,75 & 4,75 & 4,167 & 2 & 2 & 322 \\
\hline 4 & 324 & 0 & 3 & 3 & 6 & 6 & 6 & 4,500 & 2 & 4 & 324 \\
\hline
\end{tabular}




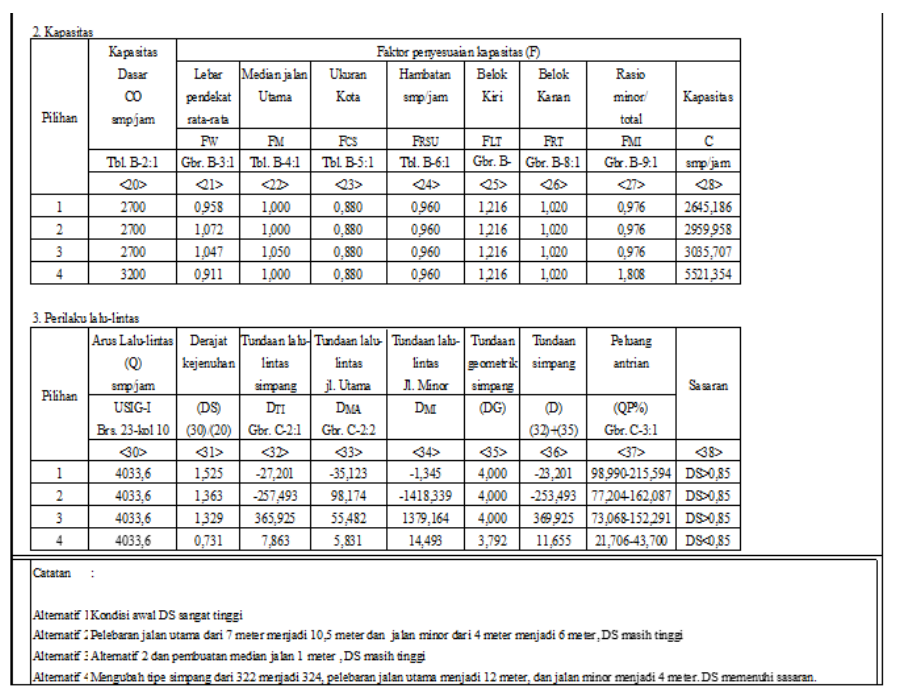

TABEL XV

Hasil Perhitungan Dengan Adanya "Supeltas"

\begin{tabular}{|lc|}
\hline \multicolumn{1}{|c|}{ Uraian } & Ada "Supeltas" \\
\hline Kapasitas & 2645 smp/ jam \\
\hline Derajat Kejenuhan & 1,525 \\
\hline Tundaan Simpang & $-23,201 \mathrm{det} /$ smR \\
\hline Peluang Antrian & $98,990 \%-215,594 \%$ \\
\hline
\end{tabular}

TABEL XVI.

Formulir USIG I - Simpang Tak Bersinyal Tahun 2018 (Supeltas dihilangkan)

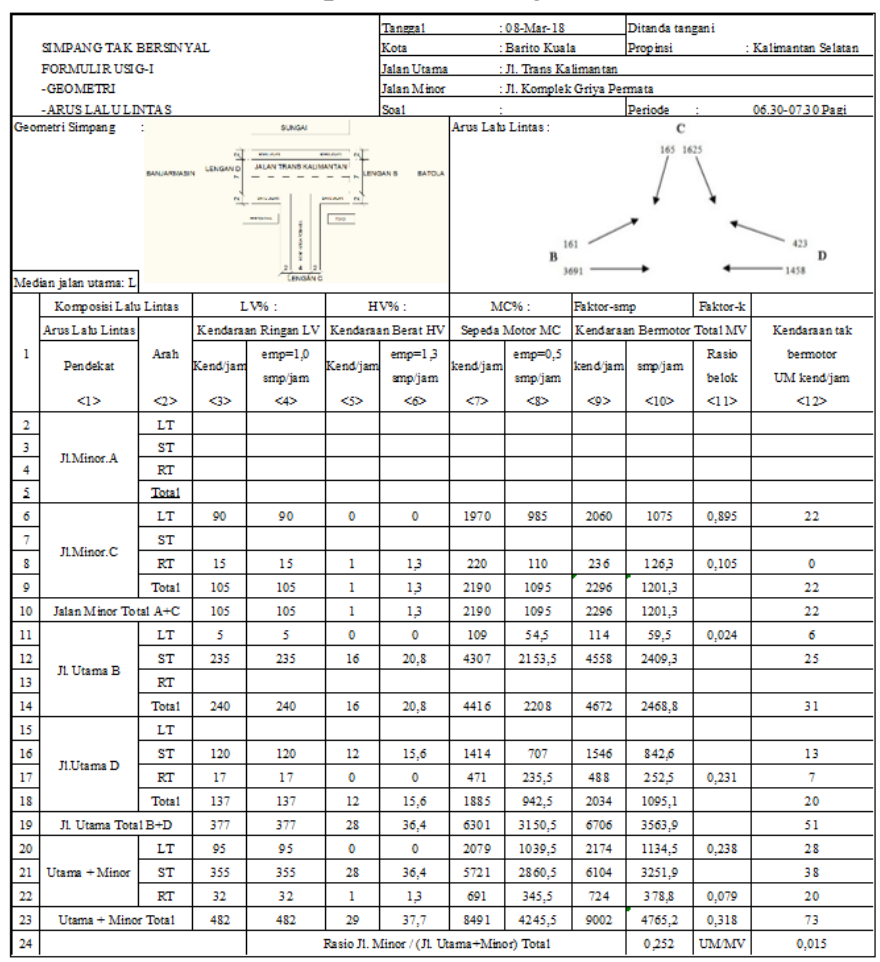

TABEL XVII

Formulir USIG II - Simpang Tak Bersinyal Tahun 2018

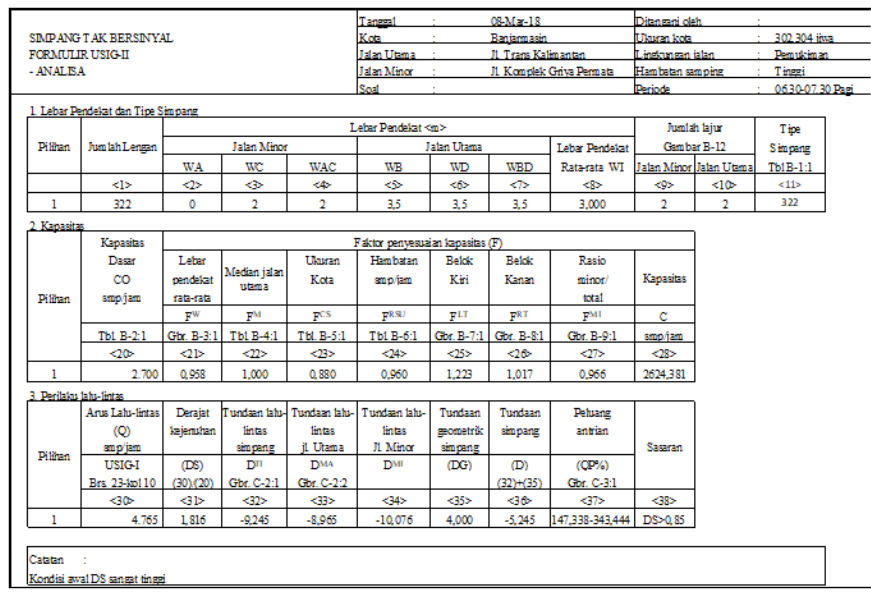

TABEL XVIII

Hasil Perhitungan Tanpa "Supeltas"

\begin{tabular}{|lc|}
\hline \multicolumn{1}{|c|}{ Uraian } & Tanpa "Supeltas" \\
\hline Kapasitas & $2624 \mathrm{smp} / \mathrm{jam}$ \\
\hline Derajat Kejenuhan & 1,816 \\
\hline Tundaan Simpang & $-5,245 \operatorname{det} / \mathrm{smp}$ \\
\hline Peluang Antrian & $147,338 \%-343,444 \%$ \\
\hline
\end{tabular}

Dari tabel XV dan XVIII diatas, dampak adanya Supeltas terhadap kinerja ruas Simpang Jalan Trans Kalimantan-Komplek Griya Permata yang dinyatakan indikator perhitungan sebagai berikut:

1. Kapasitas kinerja simpang tidak bersinyal tiga lengan dengan adanya "Supeltas" adalah 2645 smp/ jam dan tanpa "Supeltas" adalah 2624 smp/ jam.

2. Derajat kejenuhan (DS) dengan adanya "Supeltas" adalah 1,525 dan tanpa adanya "Supeltas" 1,816.

3. Tundaan simpang dengan adanya "Supeltas" adalah -23,201 det/ smp dan tanpa adanya "Supeltas" adalah $-5,245 \mathrm{det} / \mathrm{smp}$.

4. Peluang antrian dengan adanya "Supeltas" adalah $98,990 \%$ - 215,594\% dan tanpa adanya "Supeltas" adalah 147,338\% - 343,444\%.

\section{KESIMPULAN}

Kesimpulan penelitian ini adalah dari enam hari sampel pengambilan data pada jam sibuk pagi, siang dan sore untuk kondisi dengan dan tanpa adanya Supeltas dapat dilihat dari nilai DS yang 
diperoleh. Tanpa adanya "Supeltas" derajat kejenuhan (DS) mencapai 1,816 dan dengan adanya "Supeltas" derajat kejenuhan (DS) hanya sebesar 1,525. Sehingga dapat disimpulkan keberadaan "Supeltas" membuat dampak positif untuk mengurangi derajat kejenuhan (DS). Penurunan derajat kejenuhan (DS) sebesar 0,291 atau sebesar $16,02 \%$.

\section{UCAPAN TERIMA KASIH}

Terima kasih penulis ucapkan kepada saudari Nazmi Alfiana Rizki, A.Md dan saudara Muhammad Ervin Perdana, A.Md yang telah berkontribusi besar dalam pengambilan data yang menunjang artikel ini.

\section{REFERENSI}

2016. Lah...Dulu Difasilitasi, Sekarang Para Supeltas Ini Akan Ditertibkan. Pro Kalsel Radar Banjar. 31 Desember 2016. Banjarmasin.

Direktorat Jendral Bina Marga. 1997. Manual Kapasitas Jalan Indonesia (MKJI). Departemen Pekerjaan Umum. Jakarta.

Firdaus, Amalia. Dkk. 2015. Perencanaan Pengendalian Lalulintas di Persimpangan Jalan Sekitar Jembatan Kuncir Kabupaten Nganjuk Jawa Timur. (http://iptek.its.ac.id/index.php/jats/article/down load/1585/1362 diakses tanggal 17 September 2018).

Khoirina, Coni. 2016. Motivasi Menjadi Seorang Sukarelawan Pengatur Lalulintas (Supeltas). Skripsi. Fakultas Psikologi Universitas Muhammadiah Surakarta. Surakarta.

Patniawati, Hebby Dwi. 2015. Distribusi Arena Polisi Cepek (Studi Mengenai Habitus, Modal dan Arena pada Praktek Sosial Polisi Cepek di Ketintang Selatan). Jurnal Paradigma Volume 3 No 2 Tahun 2015. (http://jurnalmahasiswa.unesa.ac.id/index.php /paradigma/issue/view/822 diakses tanggal 10 Oktober 2018).

Presiden Republik Indonesia. 2006. Peraturan Pemerintah No. 34 Tahun 2006 tentang Jalan. Jakarta.
Provinsi DKI Jakarta. 2007. Peraturan Daerah tentang Ketertiban Umum. Jakarta.

Rorong, Novriyadi. 2015. Analisa Kinerja Simpang Tak Bersinyal di Ruas Jalan S Parman dan Jalan di Panjaitan. (https://media.neliti.com/media/publications/14 0650-ID-analisa-kinerja-simpang-tidakbersinyal.pdf diakses tanggal 17 September 2018).

Wahyuni, Asal dan Erlin Mulyadi. 2016. Supeltas dan Pelican Crossing: Ragam Inovasi Pelayanan Publik di Kota Surakarta. Jurnal Analisis dan Pelayanan Publik Volume 2, Nomor $\quad 1, \quad$ Juni 2016 (http://journal.unhas.ac.id/index.php/jakpp/articl e/view/1518 diakses tanggal 11 Oktober 2018). 